\title{
The Eemian interglacial in the North European plain and adjacent areas
}

\author{
Charles Turner ${ }^{1}$ \\ 1 Department of Earth Sciences, The Open University, Milton Keynes MK7 6AA UK \& \\ The Godwin Institute of Quaternary Research, Department of Geography, University of \\ Cambridge, England; e-mail: C.Turner@open.ac.uk
}

Received: 3 April 2000; accepted 13 April 2000

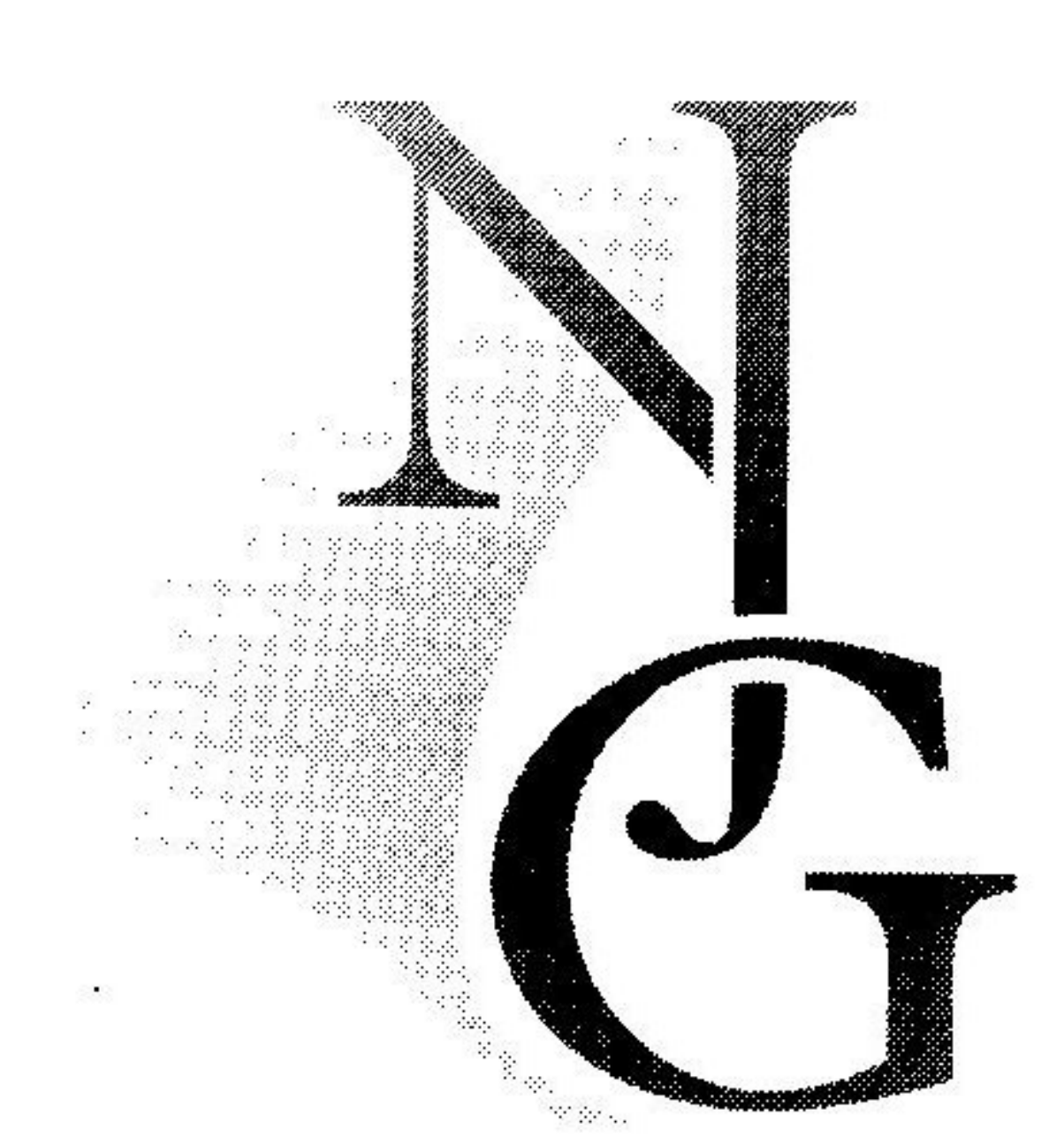

\begin{abstract}
Many small deposits of Eemian age, including the stratotype, are found right across the North European plain. In adjacent areas, this interglacial is known by local names such as Ipswichian (Britain), Luhe or Ribains (France), Riss-Würm interglacial (Alps) and Mikulinian (Poland and Russia). It correlates primarily with MIS 5e of the deep-sea stratigraphy, though boundaries may not be exactly the same. Basins containing Eemian sediments rest directly on morainic deposits of all three Saalian ice advances, which must all, therefore, fall within MIS 6.

Indicator species of both plants and animals suggest that mean July temperatures in the early-temperate part of the interglacial were warmer than during the Holocene. For many years, palynologists have recognised a very uniform succession of temperate tree acme pollen zones and a substantial late-temperate expansion of Carpinus as hallmarks of this interglacial across much of northern Europe. In southern England, however, deposits with a similar pollen signature are being recognised on stratigraphic and palaeontological grounds as characterising not only the Ipswichian but also the previously poorly-defined interglacial stage correlating with MIS 7. High Carpinus values are known from these latter sites and from the Le Bouchet interglacial of the French Massif Central, also clearly correlated with MIS 7. Thus stratigraphic confusion and misinterpretations may have occurred at supposedly Eemian/Ipswichian sites unrelated to the glacial stratigraphy or to deep continuous records.

The uniformity and rapid development of Eemian vegetational successions may be ascribed to (1) rapid warming and the lack of any late-glacial climatic oscillation on the scale of the Younger Dryas, (2) the development of an open marine connection in the first half of the interglacial from the English Channel across the North and Baltic Seas to the White Sea and the Arctic Ocean, and (3) the occurrence of Saalian per-glacial refugia for Carpinus, not only in the Balkans but also on the Iberian peninsula, permitting much more rapid northward colonisation of Europe during this interglacial.

The question of climatic events within the Eemian is far from settled. Not only is the ice-core evidence ambiguous and awaiting further clarification, but the scale and synchroneity of proposed events at different continental sites in both northern and southern Europe show no clear pattern at present; clearly there is a need for more detailed investigation and interpretation. Likewise there is ongoing debate about the duration of this interglacial and its detailed correlation with the deep-sea core record and events within the North Atlantic Ocean.
\end{abstract}

Keywords: Eemian; interglacial; Ipswichian; Late Pleistocene; North European plain; palynology; stratigraphy

\section{Introduction}

It is certain that the last interglacial stage, the Eemian, has been recognised and studied for longer and in greater detail in the area of the North European plain than in any other region. The area concerned is a broad belt of gently undulating lowland terrain stretching from the Netherlands in the West to Russia in the East, most of which was intensively glaciated during at least the Saalian and Elsterian stages of the Pleistocene but in part lay outside the maximum southerly limits of the last, Weichselian ice sheet. It is also probable that deposits of last interglacial age, although they occur in small isolated basins, are more 
frequent in parts of this area than anywhere else on the Earth's continental land masses. Both the original stratotype proposed for the Eemian (Zagwijn, 1961, 1995) and the redefined stratotype described elsewhere in this issue (Cleveringa et al., 2000) occur within the western part of this belt.

It is from the great wealth of stratigraphical, palynological and palaeontological studies that have been carried out right across this region of northern Europe that some of the most important observations about this interglacial stage have been originally made - for example, that the Eemian is the most recent fully temperate stage preceding the Holocene, that its thermal maximum was generally slightly warmer than that of the Holocene, that consequently the interglacial rise in eustatic sea level was slightly higher then than at any time during the present temperate stage, and that the duration of the interglacial - as strictly defined - appears to have been shorter than the Holocene. Evidence for some of these observations is reviewed briefly in the present contribution.

\section{The stratigraphical position and identification of Eemian sequences}

To understand the reasons for the abundance of basins with Eemian sediments, it is necessary to con- sider the nature of the deposits that underlie, or are closely associated with them. The belt of territory in which Eemian deposits are principally found corresponds to a large extent with landscapes where tills of Saalian age lie close to the surface (Fig. 1). The basins in which lakes and ponds existed during the Eemian are usually related to kettle holes (dead-ice hollows), meltwater channels or intra-morainic basins where sedimentation commenced following deglaciation in the Late Saalian and continued into or even right through the succeeding interglacial stage, depending on the size and topographical characteristics of individual basins. Where Pleistocene fluvial aggradations within river valleys are preserved, Eemian sedimentation may be represented by floodplain meander cutoff lake deposits, though these tend to represent only restricted intervals within the interglacial. At some sites, successions of both interglacial and glacial sediments may be preserved in subsiding basins as a result of subrosion where salt deposits occur at depth.

It has long been recognised that the Saalian has a complex history, and that it is represented in the North European plain by three suites of tills. Ehlers (1983) refers to these as 'Older Saalian', 'Middle Saalian' and 'Younger Saalian' tills. Elsewhere these have been called Drenthe I, Drenthe II and Warthe tills or, alternatively, Saale I, Saale II and Saale III

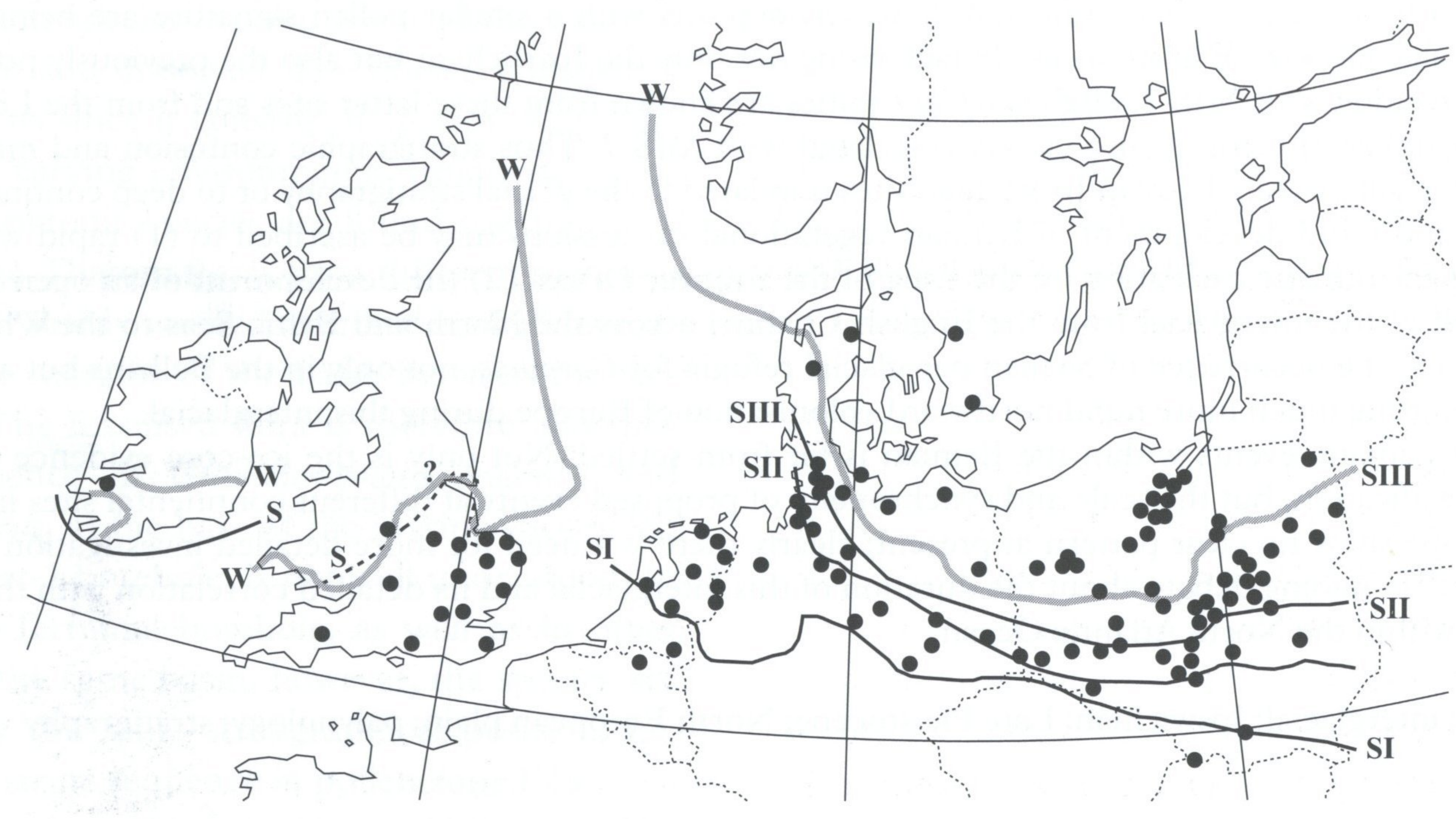

Fig. 1. Sites of Eemian Interglacial deposits in relation to glacial limits of Saalian and Weichselian age ice advances. Many further published and unpublished sites could be added. Glacial limits are approximate.

$\mathrm{W}=$ limits of Weichselian/Devensian/Midlandian ice advances.

$\mathrm{S}=$ limits of Saalian/'Wolstonian'/Munsterian ice advances;

Sl =older Saalian; SII = middle Saalian; SIII = younger Saalian (following Ehlers, 1983). 
tills, but - as Ehlers warns - the same names have been applied to different units in some areas. Approximate glacial limits for the three Saalian ice advances that deposited these tills are shown on Figure 1. In eastern Europe, different local names are generally used for tills of Saalian age (Ehlers et al., 1995). In the western part of the North European plain the Older Saalian or Drenthe I glacial advance was by far the most extensive, reaching west into the Netherlands and southwards into the northern Rheinland and to the margins of the Harz mountains (Ehlers \& Stephan, 1983). By contrast, the Younger Saalian or Warthe ice margin lies just to the West of Hamburg and does not extend far south into Niedersachsen. It is not surprising that on the fresher, undulating topography associated with this Younger Saalian glacial episode that the most abundant concentrations of small basins with Eemian infills occur; this is particularly true of northern Niedersachsen (see NLfB, 1993) and also of some areas of Poland and, no doubt, elsewhere. Here the evidence seems to point to a fairly rapid sequence of ice-sheet decay, climatic warming and the inception of interglacial conditions. Although there have been claims of evidence at a few sites for a small climatic oscillation within the Saalian late-glacial, this is not evident generally in northern Europe and certainly no such initial climatic oscillation on anything like the scale of the Younger Dryas preceding the Holocene occurred there.

There has been a long-running controversy about the status, number and stratigraphical position of interglacial stages and their deposits within the interval between the Holsteinian and Eemian (see Turner, 1998). This is relevant to the present discussion because of long-running and persistent debates as to whether there might, among the suite of interglacial deposits generally assigned to the Eemian, lie sites belonging to an older interglacial stage with a similar pollen signature. Deep cores from the maar lakes of the French Massif Central (De Beaulieu \& Reille, 1995) have provided virtually conclusive evidence for two fully temperate interglacial stages and a number of interstadials between the Eemian and Holsteinian.

Some investigators have claimed that a temperate interval, the 'Treene interglacial', occurred in northern Germany following the Older Saalian (Drenthe I) glacial event and before - and separate from - the Eemian (Picard, 1960; Stremme, 1964). This claim is based on the stratigraphy of the Rotes Kliff section on the island of Sylt, where the Drenthe I till has been interpreted as having been affected by two distinct episodes of paleosol formation (Felix-Henningsen, 1983; but see also Stephan \& Menke, 1994). Nevertheless, no actual occurrences of interglacial sedi- ments lying between the Drenthe I and younger Saalian tills have ever been demonstrated in the region.

Most evidence suggests that the now substantiated post-Holsteinian but pre-Eemian interglacial events pre-date all three recognised subdivisions of the Saalian glaciation (Erd, 1970; Litt \& Turner, 1993; Urban, 1995). The most compelling evidence for this is not based on palynological characteristics of interglacial vegetational successions but on the actual stratigraphical contexts of undoubtedly Eemian sediment accumulations with respect to the underlying Saalian till sequence. These can be well demonstrated from sites in the Netherlands and northern Germany, though similar evidence could be cited from Poland and elsewhere. At the original Eemian stratotype at Amersfoort, the Eemian sedimentary succession was interpreted by Zagwijn (1961) as being deposited within a dead-ice hollow in the surface of sands of glacial origin overlying Drenthe I (i.e. Older Saalian) till. A similar close relationship with the Drenthe I till is shown at Osterwanna (Behre, 1974), where the interglacial sediments lie within a hollow within the till. At Quakenbrück (Hahne et al., 1994), the Eemian sediments occur in 'the largest and deepest glacier-tongue basin' in Niedersachsen, enclosed by the great Older Saalian push moraines of the Dammer and Fürstenauer Berge. Here the lacustrine sequences pass down conformably into glacial silts and sands that overlie and are closely associated with Drenthe I till. Further East, in the Saale/Elbe area, the Eemian deposits at Gröbern and Grabschütz (Litt, 1990; Wansa \& Wimmer, 1990) show similar relationships to the Older Saalian glacial deposits. These Eemian successions clearly directly succeed the melting of the Saalian ice, with no conceivable possibility that the basins would have remained open during some intermediate temperate interval, but equally important is that the sequences at Amersfoort, Osterwanna and Quakenbrück all pass upwards into Weichselian deposits in which the characteristic sequence of Early Weichselian interstadials is clearly recognisable. The picture is completed by the Eemian sites at Oerel (Behre \& Lade, 1986), where the sequence of Eemian and Early Weichselian deposits occur in a basin behind, in this case, the Middle Saalian Lamstedt push moraine, and at sites such as Schalkholz (Stremme \& Menke, 1980; Ziemus, 1981), Rederstall (Menke \& Tynni, 1984) and other localities in Schleswig Holstein (Ziemus, 1980; Menke, 1992), where the basins in which Eemian sediments have accumulated are clearly associated with melting of younger Saalian, i.e. Warthe, ice masses. The key point is that this implies that buried ice blocks associ- 
ated with all three Saalian ice advances remained frozen until the climatic amelioration that heralded the Eemian interglacial. All three advances must belong to the same glacial stage.

The critical concept in accounting for the distribution of interglacial deposits must be that of 'accommodation space'. The majority of Eemian deposits in the area of the North European plain are associated with troughs of some form or other in glaciated topography, more rarely with fluvial sequences. Further north, such deposits are in fact occasionally preserved below the later Weichselian glacial tills. A similar situation appertains to the relatively frequent interglacial deposits of Holsteinian age, which were laid down in a landscape deeply affected by the Elsterian glaciation. The interglacial stages now recognised between the Eemian and the Holsteinian have left very little record, precisely because they were apparently not preceded by major glacial incursions into the North European plain, so that few sedimentary basins were formed, and much of the landscape was then further scoured by the Saalian ice advances.

These observations are of particular importance in explaining the situation with regard to Eemian - locally named Ipswichian - deposits in the British Isles and northern France which adjoin the area under consideration. In the British Isles, the limits of the 'Wolstonian' glaciation, the equivalent of the Saalian, are difficult to recognise; indeed the original stratotype is now deemed to be of Anglian (Elsterian) age. It is probable that in most areas the maximum extent of the 'Wolstonian' ice advance co-incided quite closely with that of the later Devensian (Weichselian) glacial stage. Consequently, virtually no glacial basins, such as kettle holes, infilled with last-interglacial sediments have survived. In the midland and southern counties of England, which lay outside the limits of the Devensian glaciation, quite a number of fluvial deposits, containing organic deposits and/or faunal assemblages with often abundant remains of the larger temperate mammals, have been ascribed to the last, i.e., the Ipswichian interglacial. The organic deposits represent the infills of floodplain cut-off lakes, and - as might be expected - cover only restricted intervals of interglacial time, in contrast to the sometimes complete interglacial coverage recorded from basins of glacial origin in Germany and Poland. Two longer lacustrine sequences in a basin of uncertain origin at Wing (in Rutlandshire) (Hall, 1980) and at Bobbitshole (in Suffolk), the Ipswichian stratotype (West, 1957), still represent only parts of the interglacial. Consequently, the reconstructions of the Ipswichian vegetational succession (Phillips, 1974; West, 1980) are composite and based on infor- mation from a range of sites. Nowhere has an actual pollen diagram representing the entire interglacial been achieved.

The situation with regard to the stratigraphy of Ipswichian deposits in southern Britain has been further complicated by recent re-evaluation of the terrace stratigraphy of the Thames (Bridgland, 1994) and Avon (Maddy et al., 1991) rivers. In the lower Thames valley, West investigated a series of interglacial deposits that appeared to show a virtually identical pollen sequence to that of the Ipswichian stratotype at Bobbitshole (West et al., 1964; West, 1969). Bridgland (1994), however, has concluded that more than one interglacial stage is represented by these deposits in the series of Thames terraces, which were previously considered all to be of Ipswichian age. The famous interglacial deposits at Trafalgar Square (London), which have a very rich fauna of large mammals, can undoubtedly be correlated with the Ipswichian stratotype at Bobbitshole, particularly on the basis of distinctive elements in their beetle faunas (Coope, 1974, 1990; Aalbersberg \& Litt, 1998) with a wealth of species, including - amongst many others - Bembidion elongatum, Cybister lateralimarginatus, Caccobius schreberi, Oniticellus fulvus and Scolytus koenigi, none of which reach as far North as Britain today. It is generally agreed that these deposits fall within an interglacial stage, the Ipswichian interglacial sensu stricto, which can be correlated with certainty with both the Eemian of continental Europe and MIS (Marine Isotope Stage) $5 \mathrm{e}$ of the deepocean record. On stratigraphical grounds, Bridgland believes that the interglacial deposits at sites in Essex at Aveley (West, 1969) and at Seven Kings, Ilford (West et al., 1964) actually belong to an older interglacial, equivalent to MIS 7, despite having pollen signatures similar to those of undoubtedly Ipswichian sequences. He assigns the deposits at Grays Thurrock (West, 1969) and Purfleet (Hollin, 1977) to a stage correlatable to MIS 9. The alternative view that all these interglacial deposits still belong to a single stage has been maintained by Gibbard (1995). Quite independent support for the idea that these sites belong to separate interglacial stages from the Ipswichian stratotype is provided by vertebrate and molluscan faunal evidence (Preece, 1995, 1999; Schreve, 1997). For example, finds of Hippopotamus are believed to be restricted to deposits of Ipswichian (sensu stricto) age (MIS 5e), as at Trafalgar Square, whilst the fluvial mollusc Corbicula fluminalis seems never to be found in a true Ipswichian context, but occurs regularly in both interglacial suites that have been re-assigned by Bridgland to older stages. Similar evidence for the stratigraphical distribution of Corbicula is now report- 
ed also from the Netherlands (Meijer \& Preece, 2000 - this issue). Other taxa show similar patterns, providing a good palaeontological basis for a more accurate separation of Eemian and older late Middle Pleistocene sites.

Two aspects deserve attention in this context. The first is that it is in fluvial sequences outside the Saalian glacial limits - such as those of the Thames, the Somme (Antoine, 1994) and the Maas (Van Kolfschoten et al., 1993) - that deposits of the 'missing' interglacial stages between the Holsteinian and the Eemian are most likely to be preserved. The second is that well-recognised palynological criteria - the succession of pollen maxima of expanding temperate tree genera in early-temperate substages and the abundance of Carpinus in late-temperate pollen assemblages - appear not to be unique to Eemian/Ipswichian interglacial successions in the latter part of the Pleistocene. Whether in some cases older sequences have been misinterpreted as being of Eemian age is a matter that needs to be borne in mind, taking all palaeontological evidence into account.

In Ireland, virtually the whole island was ice-covered during Munsterian (Saalian) glacial times, whereas only a small area of southern Ireland remained unglaciated at the Midlandian (Weichselian) glacial maximum. It is not entirely surprising, therefore, that there are virtually no well-developed or undisturbed last-interglacial sedimentary sequences known from Ireland and, so far, no firmly established pollen record (Coxon, 1993). Here again 'accommodation space' appears to be a crucial factor, since in areas unglaciated during the Midlandian, there are - unlike the case of southern Britain - few rivers with alluvial terrace systems sufficiently developed to be likely to preserve interglacial fluvial sediments.

\section{Vegetational history of the Eemian}

Modern stratigraphical and vegetational studies of the Eemian effectively began with the investigations of Jessen \& Milthers (1928) into fresh-water interglacial sequences in Denmark and northern Germany. The range and detail of their work is still astonishing today. The zonation put forward by Jessen remained for many years the standard scheme for describing Eemian pollen diagrams throughout northern Europe, and the two schemes most commonly used today for regional comparisons in northern and central Germany, those of Selle (1962) and of Menke \& Tynni (1984) are essentially elaborations of Jessen's original zonation scheme. With the geographical expansion of interglacial studies, many local pollen assemblage biozone series have subsequently been de- scribed, but because of a marked uniformity of vegetational development across much of Northern Europe during the Eemian, correlations in terms of vegetational facies can be made easily. Essentially these pollen-zonation schemes, whether local or regional, are based on successive acme zones for different temperate tree taxa. A brief summary of some of the major zonation schemes applied to Eemian pollen diagrams in different areas (Table 1) emphasises just how similar Eemian vegetational successions appear to have been, right across Western and central Europe from Western France to Poland. In the absence of any method of precise absolute dating for the Eemian, the exact temporal relationships between parallel pollen sequences along a transect, say from West to East, across the North European plain can obviously not be determined with certainty, given leads and lags of rates of plant migration and establishment.

Amongst the plethora of publications on the Eemian (Meijer, 1998), a number of site investigations or broader publications relating to vegetational history should be mentioned, particularly those which have yielded pollen diagrams that demonstrate a more or less complete vegetational sequence through the interglacial. In France, at the margin of the area under discussion, the site of Grande Pile in the Vosges mountains (Woillard, 1975, 1978; De Beaulieu \& Reille, 1992a) is important not only because a complete vegetational succession through the interglacial is present, but also because at this site, for the first time in 1977, this long pollen sequence, extending from the late Saalian to the early Holocene - and recording the distinctive vegetational fluctuations of the Eemian, the Early Weichselian interstadials and Pleniglacial - provided a convincing correlation with the deep-ocean oxygen isotope record and clearly proved the equivalence of the Eemian with substage $5 \mathrm{e}$ of the marine stratigraphy. Sites in the Massif Central, Le Bouchet and Ribains (Reille \& De Beaulieu, 1990; Pons et al., 1992) and at Les Echets near Lyon (De Beaulieu $\&$ Reille, 1984) have reinforced this picture, again providing full sequences through the Eemian interglacial and the subsequent Early Würmian interstadials.

In the Netherlands, the critical sequences are those from Amersfoort (Zagwijn, 1961), defined as the original stratotype for the Eemian, and that from the redefined stratotype at Amsterdam-Terminal (Cleveringa et al., 2000; Van Leeuwen et al., 2000 - both this issue) which has yielded a fuller sequence of pollen zones. Both of these sites also record the rise of the sea level and the marine transgression during the early part of the interglacial and its subsequent fall, as well as climatic deterioration and the transition to the 
Table 1. Eemian pollen-zonation schemes for several areas of Western and North-central Europe, showing formal zone names (in bold) and characteristic pollen taxa. Zone names may, therefore, relate either to specific pollen taxon acmes or to most abundant or characteristic taxa.

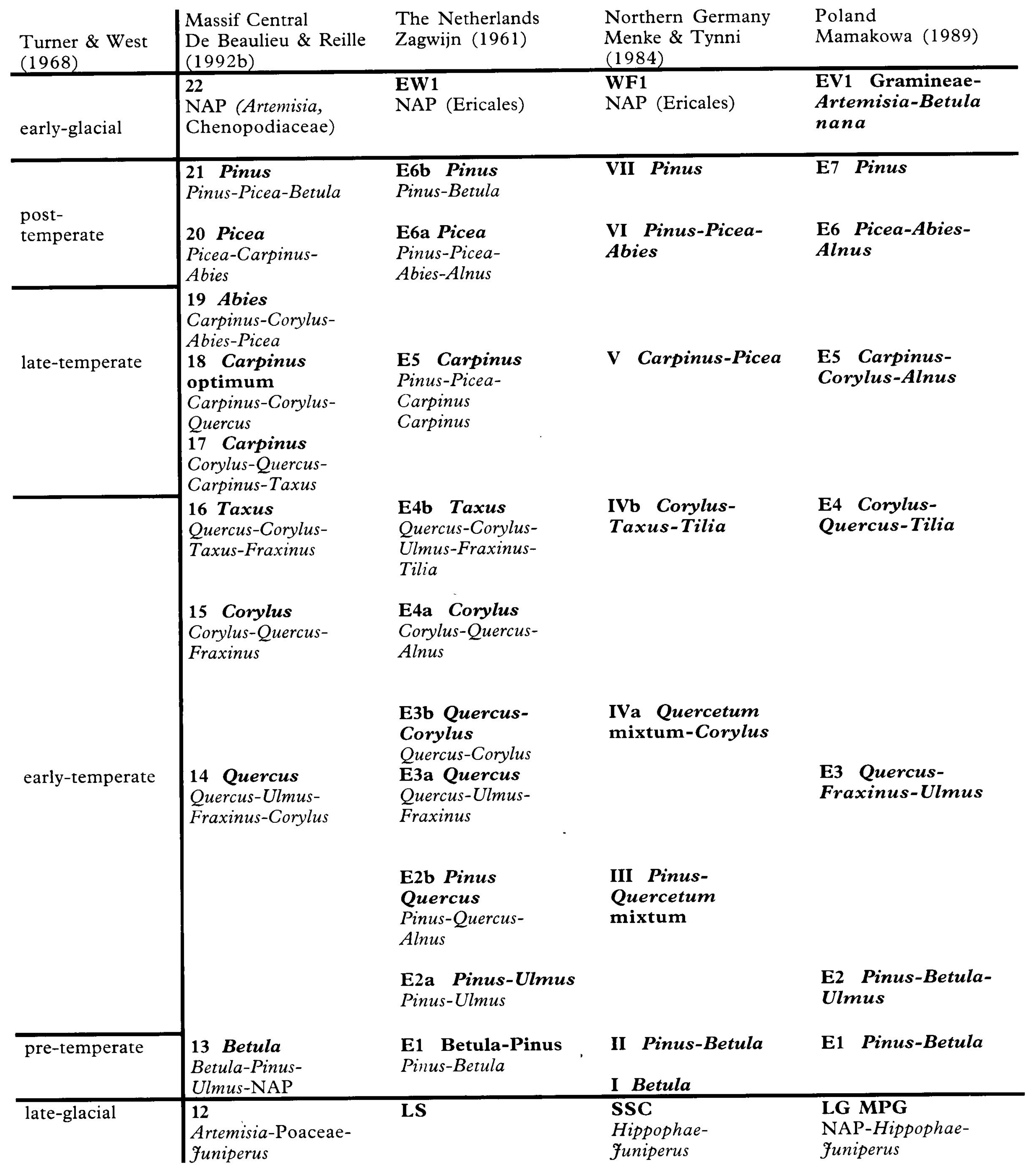

Early Weichselian (here using the northern European terminology) and then its characteristic interstadials. As has already been mentioned, a number of sites in northern Germany have yielded pollen diagrams covering the complete interglacial cycle, particularly Quakenbrück (Hahne et al., 1994), Gröbern (Litt, 1990) and Grabschütz (Litt, 1990), as has that at Hollerup in Denmark (Andersen, 1965, 1966). In Poland, the numerous sites where pollen analysis has been applied to sediments of Eemian (Mikulinian) age - many with complete interglacial sequences have been reviewed in detail by Mamakowa (1989), but perhaps the most detailed sequence is from Imbramowice.

The most striking feature of pollen diagrams from the Eemian is the strong parallelism in vegetational development right across Europe from the Massif Central, across the North European plain to Poland and beyond, though, of course, there are a number of distinctive regional features; these will be discussed later. This parallelism is illustrated by the pollenzonation systems and their dominant taxa that have been proposed for different sites and regions across the area under consideration (Table 1). In this inter- 
glacial, above all others the succession of vegetational substages described by Turner and West (1968) (pre-, early-, late- and post-temperate), closely linked to the interglacial subdivisions of Firbas (1949) and Iversen (1958) (protocratic, mesocratic, oligocratic and telocratic), is clearly recognisable.

Where represented at sites in the North European plain, the virtually treeless Saalian late-glacial appears to be short, often represented by just thin sequences of polleniferous sediment, though these may pass down conformably into glacial silts. At most sites, herbaceous taxa dominate the pollen assemblages, though Betula nana (dwarf birch) and Salix spp. (dwarf willows) were present, as is sometimes confirmed by plant macrofossils. The end of this lateglacial was at most sites heralded, as during the Late Weichselian, by expansion of funiperus (juniper). At no site is there any convincing evidence for any climatic oscillation on the scale of the Allerød interstadial and Younger Dryas stadial during the Weichselian/Würmian Late-Glacial, despite suggestions by Knudsen (1994) that studies of foraminifers indicate such an oscillation in the Baltic.

Across the whole region the initial pre-temperate expansion of woodland and forest took place through the spread of Betula (tree birches), followed by Pinus (pine). In contrast to the Holsteinian and earlier interglacials, it is clear that Picea (spruce) played no role in this initial expansion of boreal forest across this area of Europe during the Eemian, although in Russia and North-East Poland a very early short-lived expansion of spruce, together with pine, is reported from the Saalian late-glacial (Mamakova, 1989). In almost all pollen diagrams, the earliest of the temperate deciduous taxa to appear and expand was Ulmus (elm), followed by Quercus (oak). which rapidly became dominant, and then Corylus (hazel). Hazel percentages are higher than in earlier interglacials, though generally not as high as in Holocene pollen diagrams, where this tree expanded obviously before rather than after oak. Alnus (alder) was often but not always abundant during this early-temperate vegetational substage, but the major regional vegetational differences at this time relate to the presence of Taxus (yew) and Tilia (lime). Taxus, which expands after Corylus in the vegetational succession, was clearly a significant element in the vegetation at some sites, for example Le Bouchet, Grande Pile, Oerel, Hollerup and some Polish sites (figure 20 in Mamakowa, 1989), but sparser or absent in others. This probably relates to local geological conditions and, in older palynological investigations, to failure to record this taxon adequately. The distribution during the Eemian of Tilia, a taxon represented in fact by several species at the time, shows a much stronger geographical pattern. It was rare or absent in Western areas such as France and Britain, yielded pollen percentage values of about $5 \%$ in the Netherlands, slightly higher values at Oerel, Grabschütz and Gröbern, but much higher values at some sites in northern Germany, Denmark and Poland (Andersen, 1975; Menke \& Tynni, 1984; Mamakowa, 1989), where lime must for a period have dominated the forests.

A highly characteristic feature of the late-temperate vegetational substage of Eemian sites in all areas of the North European plain was the immigration and rapid population expansion of Carpinus betulus (hornbeam). In most regions, Eemian pollen diagrams show higher percentage values for Carpinus than have been found in any previous interglacial record or for the Holocene, although - as mentioned earlier - it now seems likely that in some regions Carpinus was also abundant in the late-temperate substage of the previous, poorly recognised interglacial stage, for example in the Le Bouchet interglacial of the Massif Central (Reille et al., 1998). Carpinus maxima in these diagrams may range from $40 \%$ to $70 \%$, with the other major pollen contributors being Corylus and $\mathrm{Al}$ nus, where fen woodland was locally important. Although other temperate trees, like Quercus, Fraxinus (ash) and Taxus, were still part of the forest community, it is clear that Carpinus must have been the dominant tree across an enormous swathe of Northern Europe, from Britain to Western Russia.

Several important points may be made about the occurrence of Carpinus in North-Western Europe during interglacial stages and particularly during the Eemian. In Middle and Upper Pleistocene, as well as the Holocene vegetational successions, Carpinus immigrated and rapidly expanded during the late-temperate substage, when this tree to a considerable extent was able to displace other temperate deciduous taxa within the forests covering the North European plain. Both pollen morphology and macrofossil remains suggest that the species concerned is $C$. betulus. A number of explanations have been put forward for this vegetational succession, namely that the late arrival of Carpinus resulted from a slower rate of migration from its per-glacial refugia, that it required fully mature or somewhat leached soils to compete successfully with oak, and that significant climatic changes during the second half of interglacial stages favoured its expansion. None of these explanations are fully convincing, though it is clear that, like Fagus (beech) and Tilia (lime), mature Carpinus cast a deep shade, which may give this tree a competitive advantage over more light-demanding species. Significantly in interglacial pollen diagrams from Mediterranean 
regions (Follieri et al., 1988; Tzedakis, 1994) a similar pattern can be observed, with Carpinus expanding during the latter part of interglacial vegetational successions, even though refugia were probably not far away.

Nevertheless migrational factors must have had some significance in northern Europe. Huntley and Birks (1983) have.shown that the Balkan area apparently provided the only per-glacial refugia for this tree during the last glacial stage, and they were able - by mapping pollen frequencies - to trace how, during the Holocene, it migrated northwards into Poland and eastern Germany and only subsequently across Germany, then westwards to France and southern England, where it arrived about $2500 \mathrm{BP}$. It failed to cross the Pyrenees into Spain. In the Eemian, however, estimates of the duration of the interglacial (to be discussed later) suggest that Carpinus had already reached the North European plain only about 4000 years after the onset of the interglacial. A recent pollen diagram from marine sediments offshore of Portugal (Sánchez Gõni et al., 1999) clearly indicates that Carpinus was present on the Iberian peninsula during the Eemian. It is thus probable that this tree had refugia during the Saalian not only in the Balkans but in South-West Europe as well. This would certainly give it the opportunity to recolonise the North European plain much more rapidly than during the Holocene. Of incidental note is the fact that Carpinus was virtually absent from the French Massif Central during the Praclaux interglacial, the presumed equivalent of the Holsteinian (Reille \& De Beaulieu, 1995). Thus history may have been repeating itself, with Carpinus becoming extinct in its Iberian refugia during both the severe Elsterian and Würmian/Weichselian glacial stages, but recolonising at some time during the intervening temperate intervals. Clearly this matter requires further study.

There can be no doubt that soil conditions were also important in determining the abundance of Carpinus at individual sites. Over wide areas of the North European plain, the surface geology would have been dominated during the Eemian either by Saalian tills largely formed from a mixture of eroded Tertiary sands and silts and the residues of hard crystalline rocks from Scandinavia - or by exposures of local Tertiary strata. In either case leaching would have increasingly encouraged the formation of neutral to acid soils over much of the area, with occasional areas of more base-rich conditions, viz. where marls or limestones outcropped. Carpinus appears to fare better on such soils than most other temperate deciduous trees. In most pollen diagrams from those areas, particularly in Germany and Poland, where Tilia was frequent towards the end of the early-temperate substage, this taxon falls sharply, in company with Quercus, Ulmus and to some extent Corylus, as Carpinus expands. This replacement of other temperate trees by Carpinus is one of the major vegetational features of the interglacial. Zagwijn (1996) suggested that this transition might be considered as a more or less synchronous horizon across northern Europe, and other workers (Field et al., 1994) have even interpreted it as a response to major climatic change.

The other tree taxon that is usually associated with late-temperate vegetation in European interglacial sequences is Abies (silver fir), generally assumed to have been Abies alba, though this is only rarely confirmable by identification of macrofossil remains. This tree was widespread across the eastern part of the North European plain at this interval of the Eemian, though it was nothing like as abundant as it had been during the Holsteinian. It probably reached its northern limit at about the latitude of southern Denmark, since it is absent at Hollerup (Andersen, 1965, 1966). It became less abundant in the West, for example at most sites in the Netherlands, and was probably absent from Britain, perhaps because it failed to cross the marine barrier that separated South-East England from continental Europe at the time.

Post-temperate vegetation across the whole area is characterised by the development of boreal forest, dominated by Pinus, Betula and Picea, but also of extensive heath and bog, as indicated by high frequencies of Calluna pollen and Sphagnum spores, suggesting high rainfall and cumulative leaching and acidification of soils. Picea spread far beyond its present range, for example being abundant at sites in the Massif Central (De Beaulieu \& Reille, 1995), though, similarly to Abies, there is very little evidence that this tree succeeded in reaching the British Isles at this time, though it was present there during the Devensian Chelford (Brørup) interstadial (Simpson \& West, 1958).

\section{Duration of the Eemian}

An early attempt to estimate the duration of the Eemian was made by Shackleton (1969), but his conclusions were based primarily on then current age estimates of the deep-ocean record and sedimentation rates in marine cores. Nevertheless he recognised that the interval under consideration, just MIS $5 \mathrm{e}$, which he correlated with the continental Eemian of NorthWest Europe, was comparatively short - he suggested 11,000 years. Today there is still argument about the precise ages, within 2000-3000 years, of the upper and lower boundaries of MIS 5e, largely because 
these boundaries are defined at mid-points between oscillations of oxygen isotope curves, whereas it is the peaks or troughs of those curves to which dating attempts by astronomical calibration (see, among others, Martinson et al., 1987) or radiometric dating of high sea-level stands have been applied.

A more direct approximation of the duration of interglacials is possible, partly by measuring and partly by estimation, on the basis of the development of annual lamination in lacustrine deposits. Such favourable conditions have been investigated at two Eemian sites in northern Germany. At Bispingen, Müller (1974a) suggested a duration of 9,000-11,000 years for the whole interglacial, based on both direct counts of about 1900 laminations in a more or less continuous sequence covering part of the pre-temperate and most of the early-temperate substages, and estimates for the remainder of the sequence, with its good continuous pollen record, supported by a few other shorter laminated sections in the cores. At Quackenbrück (Hahne et al., 1994), the Eemian lacustrine sediments were also laminated discontinuously throughout the interglacial sequence. Counting of representative sections from different depths suggested a duration of approx. 9500 years for the interglacial, a figure roughly consistent with that of Müller.

What should be understood is that the onset of the Eemian in continental records is certain to be diachronous from south to north, at least by several hundred years, if the Weichselian Late-Glacial (as opposed to the Holocene onset) is taken as an analogue. Sánchez Gõni et al. (1999) show indeed, from marine cores offshore of Portugal, an apparently short delay in the appearance of tree-dominated vegetation after the onset of ocean warming (i.e., the estimated lower boundary of MIS 5e). On the other hand, marked cooling episodes interpreted from pollen diagrams towards or at the ends of interglacial stages, are most likely to reflect southwards incursions of polar waters in the North Atlantic Ocean and, therefore, much more likely to be synchronous events.

The combination of pollen records and a lamination chronology, albeit a hanging one, allow important comparisons to be made between the Eemian interglacial on the one hand and both the Holocene and the Holsteinian interglacial - which also has a similar lamination chronology (Müller, 1974b; Turner, 1970) - on the other. The main conclusions drawn are that, in comparison with these other two temperate stages, (1) the pre-temperate and early-temperate substages of the Eemian covered a comparatively short period of time, only about 4400 years perhaps, and (2) the whole interglacial, as defined conventionally in the continental record, was much shorter $(10,000$ years or less) than either the Holocene (about 11,500 calendar years so far) or the Holsteinian $(17-20,000$ years). On the other hand, Kukla et al. (1997), comparing the Grand Pile pollen sequence (Woillard, 1978) with sediment records and curves for planktonic foraminifers from deep-sea cores in the North Atlantic, suggest that the length of the interglacial has been seriously underestimated, that it equates not only to MIS 5e but also to the earlier part of the supposedly cool MIS $5 \mathrm{~d}$. In that case the Eemian would have lasted approximately twice as long as the time span calculated by Müller. This clearly raises a number of questions that cannot be solved without a much closer investigation of some of the evidence.

The rapid rate of development of interglacial vegetation right across Northern Europe at the beginning of the Eemian may in part be connected to the absence of any kind of late-glacial climatic oscillation, so that migrations from refugia proceeded without interruption and perhaps under even warmer conditions than occurred during the early Holocene. The comparative shortness of the earlier vegetational substages during the Eemian may, however, also have been strongly influenced by the migration rate of Carpinus. Apparently it took only 4000 years or less for this tree to attain dominance right across the North European plain, whereas it was more than 8000 years during the Holocene - admittedly in the face of human disturbance of the landscape - before this tree became established in Northern France and Southern Britain, whereas it probably took even longer for Carpinus to expand in the Holsteinian/Hoxnian (Müller, 1974b; Turner, 1970). This must be related to the observation that this taxon had refugia on both the Iberian peninsula and the Balkans at the onset of the Eemian, whereas only the more distant Balkan refugia had been extant in both the Holocene and the Holsteinian. It also suggests that the replacement of mixedoak by hornbeam-dominated forest cannot really be ascribed to progressive maturation of forest soils, though hornbeam favours neutral to slightly acid soils and may subsequently encourage this process. Rather this seems to be related to competitive factors, though climatic change may play some role.

\section{The climatic development of the Eemian}

This topic has been thoroughly investigated and discussed in two important recent papers by Zagwijn (1996) and by Aalbersberg \& Litt (1998), so that only a brief summary is given here. The two works just mentioned principally use the known present-day climatic tolerances of plant taxa, represented in the Eemian sequences across Northern Europe by pollen 
taxa or preferably plant macrofossils, which can be identified to species level. Aalbersberg and Litt also include similar information from fossil Coleoptera records. The techniques involved derive from a combination of the climatic indicator method, developed by Iversen (1944) originally using records of Viscum, Hedera and Ilex, the overlapping areal method (Grichuk, 1969, 1984) and the mutual climatic range method (Atkinson et al., 1987).

These methods are particularly appropriate for the Eemian because a number of critical, generally thermophilous species extended their ranges well beyond their present distribution limits. In the British Isles, Southern European taxa such as Acer monspessulanum and possibly Pyracantha cf. coccinea have been determined as macrofossils, far to the North of their present range. In Southern and even central Germany, primarily Balkan or more broadly South-East European taxa made their appearance: Acer tartaricum, Tilia tomentosa and Crataegus pentagyna. At the same time species that flourish best today in the more oceanic regions of western Europe - i.e., Ilex aquifolium (holly), Hedera helix (ivy) - spread eastwards into what are now regarded as more continental areas, as also did Taxus baccata (yew) and Buxus sempervirens (box). A similar pattern is recorded by aquatic plants, with Salvinia natans, Trapa natans and Aldrovanda vesiculosa all extending farther north than their present ranges and occurring with the exotic taxa Brasenia schreberi and Dulichium arundinaceum, extinct in Europe after the Eemian, but still found in North America. In addition to these plant records, there are thermophilous beetles such as Bembidion elongatum, Cybister lateralimarginatus, Caccobius schreberi, Oniticellus fulvus and Scolytus koenigi from which information on palaeotemperatures can be deduced.

It should be noted that neither Litt (Litt et al., 1996) nor Zagwijn (1996) accept the existence of more than one interglacial 'of the Eemian type'. They both use data from English sites whose stratigraphic position is now in doubt, but there is no case for questioning the bulk of data from continental northern Europe on this score.

The conclusions drawn by both Zagwijn and Aalbersberg \& Litt are, as would be expected, closely similar. Their results emphasise how over-simplistic it is to refer to any one part of the interglacial as its 'climatic optimum' - a term anyway to be avoided as ambiguous, because different organisms have different optima! Even using the term 'thermal maximum' is complex. In the Eemian, the evidence is clear that the summer thermal maximum occurred during the early-temperate substage of the interglacial, that is during zone E4a using Zagwijn's subdivision and zones II and IV of Menke \& Tynni (see Table 1), with estimated mean July temperatures in the Netherlands at least $2{ }^{\circ} \mathrm{C}$ higher than nowadays, i.e. about $19^{\circ} \mathrm{C}$, and even $20^{\circ} \mathrm{C}$ in North-Eastern Germany and Poland. Nevertheless reconstructed mean January temperatures are very similar to the present-day ones: $0^{\circ} \mathrm{C}$ in western areas such as southern England and the Netherlands and along the North Sea and perhaps Baltic coasts, but falling to $-2^{\circ} \mathrm{C}$ in more continental areas away from the coast. This is, of course, the period when most of the thermophile, often Southern European, species appear to have extended their ranges into North-West Europe and when other, probably rather xerothermic South-Eastern European species such as Acer tartaricum, appeared in Southern Germany and Poland.

On the other hand, although mean July temperatures appear to have fallen back by perhaps $2^{\circ} \mathrm{C}$ to virtually present-day levels during the late-temperate substage of the interglacial, zone E5 of Zagwijn and zone Va of Menke \& Tynni (see Table 1), the mean winter thermal maximum appears to have now developed with estimated mean January temperatures of $0^{\circ} \mathrm{C}$ to $+1^{\circ} \mathrm{C}$ across Eastern parts of the North European plain, rising to $+1^{\circ} \mathrm{C}$ to $+2^{\circ} \mathrm{C}$, well above present equivalent temperatures, in Western parts of the area. It was these mild winter conditions that permitted such frost-sensitive taxa as Ilex, Buxus and Taxus to continue their eastward expansion, well beyond their Holocene ranges, throughout the temperate zones of the Eemian. It is equally this factor that has led some interpreters (among them Kukla et al., 1997) to state simply that this was the 'climatic optimum'. Well, it certainly wasn't for the most thermophile taxa of beetles, or of vascular plants, nor for Hippopotamus!

Both Zagwijn and Aalbersberg \& Litt refer to the climate of the early-temperate part of the interglacial as subcontinental and to that of the late-temperate part as oceanic, but these terms may be ambiguous in relation to actual events in the region. Study of Eemian marine molluscan faunas suggests that at least part of the climatic warming of northern and particularly North-West Europe during the earlier half of the interglacial was related to access of warm Atlantic waters through the Strait of Dover, into the southern North Sea, and even further into the Baltic and then the White Sea. This provides also an explanation for the remarkably uniform development of vegetation across the North European plain, compared to, say, that of the Holsteinian interglacial. This marine connection through to the Baltic and White Seas was, however, probably broken prior to the late-temperate substage, as a result of isostatic uplift of areas adjacent to the Baltic. 
The final issue here is whether there have been any major climatic events within the Eemian. For many years the general view, at least among palynologists (see Litt et al., 1996; Zagwijn, 1996) has been that pollen diagrams from the Eemian suggested an interglacial with a perhaps short but relatively uneventful vegetational succession, determined by plant-migration rates, competition and gradual (not sudden nor catastrophic) climatic change. Such views were thrust into the melting pot following publications in the journal 'Nature', first of evidence of climatic instability during the last interglacial from the GRIP ice core (Dansgaard et al., 1993; GRIP Members, 1993), followed by a rebuttal of these interpretations using evidence from the GISP2 ice core (Taylor et al., 1993; Grootes et al., 1993). This controversy has generated a number of papers offering evidence for climatic fluctuations during the Eemian, but at several different times within the interglacial and of differing intensities. Frogley et al. (1999), studying a lacustrine sequence in Greece, described episodes of climatic instability during intervals at the beginning and end of the interglacial but less pronounced fluctuations, similar to those that have been recognised from the Holocene, during fully interglacial conditions. De Beaulieu \& Reille $(1989,1992 b)$ have also recognised climatic fluctuations affecting post-temperate vegetational successions at Les Echets and in the Massif Central.

Two other papers, by Björck et al. (2000) and Field et al. (1994), propose, however, more drastic climatic events within the temperate substages of the interglacial. Björck et al. have used multidisciplinary studies, particularly on sediments, diatoms and stable isotopes, to supplement the palynological investigation of this site by Andersen (1965, 1966). In particular they have identified two major but temporary falls in the lake level at the site. The first of these took place at the very end of Andersen's pollen zone 4, that is at the transition between early-temperate and late-temperate vegetational conditions at a time when, locally, Carpinus had arrived but not yet expanded, when Picea also had arrived and was expanding, when pollen frequencies of Quercus, Corylus and Taxus were in decline, but when Tilia was apparently stable. They suggest that this lake-level fall was induced by a short 'dry and cooling' event, probably associated with the closure of the connection between the Baltic Sea and the White Sea, and with consequent readjustment of oceanic and atmospheric circulation patterns. The second temporary lake-level fall took place during the post-temperate zone (Andersen's pollen zone 6), when Pinus, Picea and Betula dominated the forest. The authors suggest that it was associated with small fluctuations in some pollen curves, but it is doubtful whether these are actually statistically significant. They propose 'extreme aridity' as a possible cause of the event and/or that the now shallow lake became frozen to the base in winter. This event, too, was comparatively short-lived.

Field et al. (1994) have attempted to reconstruct Eemian palaeoclimates on the basis of comparisons with Holocene pollen surface sample data from Eurasia and North America, using the climate response surface method (Bartlein et al., 1986; Huntley, 1993) and applying it in particular to the pollen data from Bispingen (Müller, 1974a). Several of their conclusions are highly controversial and not in agreement with those of any of the aforementioned studies. Using the lamination chronology put forward by Müller, they suggest that a major oscillation in winter temperature occurred in the middle of the late-temperate Carpinus zone (zone Va of Menke \& Tynni, see Table 1). 'At its extreme the climate perhaps resembled that today in Central Siberia' (mean winter temperature down to $-20^{\circ} \mathrm{C}$ !). This event is said to be based on the decline or disappearance of several thermophilous taxa (Corylus, Fraxinus, Taxus, Tilia, Ulmus), but at the same time Carpinus shows pollen frequencies of 30$40 \%$, Corylus about $15 \%$ with the 'dip' relating to a single counting level. At other closely sampled sites in northern Germany and Poland, the curves for both Tilia and Taxus persist at frequencies of $5-10 \%$ throughout the Carpinus zone. At Hollerup, the first lake-level event occurs before the expansion of Carpi$n u s$, and Björck et al. (2000) find no evidence for any sudden fall in temperature at this later time. Furthermore, there is good evidence for taxa, intolerant of winter cold, such as Ilex and Buxus, extending their ranges eastwards at this time and even during the later parts of the Eemian interglacial, whereas Field et al. (1994) suggest that mean winter temperatures, having recovered from this extreme low, remained at about -5 to $-10^{\circ} \mathrm{C}$. This discrepancy is not considered and Müller's pollen curves for Ilex and Hedera are simply eliminated from the redrawn pollen diagram. The more likely explanation seems to be that the Bispingen site lay within an area of strongly leached soils where the more nutrient demanding trees eventually could not compete with Carpinus and its deep shading.

At sites not far distant from Bispingen, where baserich rocks are present, Tilia can be shown to have persisted through this interval (H. Müller, pers. comm.) and it would have been impossible to derive such extreme conclusions from the pollen statistics. Even given the data from Bispingen, it is really impossible to reconcile a continuous Carpinus curve of $30-40 \%$ with 
an extreme mean winter temperature fall to $-20^{\circ} \mathrm{C}$ or with any fantasy of this tree-forming, dense forests in central Siberia! The authors seem to have been overinfluenced by the recently published GRIP results. They also interpret the pre-temperate Betula and Pinus dominated zones at the beginning of the Eemian at Bispingen as typical boreal forest with mean temperatures for the coldest month at $-13^{\circ} \mathrm{C}$, analogous to the climate in central Europe and Russia, whereas it is clear from the behaviour of such trees in the Early Holocene that their role at the beginning of temperate stages has been as pioneer trees expanding before the immigration and expansion of temperate deciduous taxa and certainly not in ecological equilibrium with the warming climate. Unless the climate response surface method is used in a more careful and discriminating way, it will add more confusion than clarity to interglacial palaeoclimatology.

Finally, evidence from certain marine deposits believed to be of Eemian age must be considered. In Denmark, onshore boreholes in northern Jutland and on the island of Anholt have yielded thick sequences of Middle and Upper Pleistocene marine sediments. Knudsen (1994) and Seidenkrantz et al. (1995), principally on the evidence of studies of benthic foraminifers, have recognised interglacial successions that they ascribed to the Eemian. The foraminifers indicate incursions of cold water into the North Sea and Skagerrak-Kattegat area at two intervals during the interglacial, as well as a late-glacial climatic oscillation. Two assumptions were made specifically by these authors: firstly that the Holsteinian correlates with MIS 7, so that any post-Holsteinian temperate sequence must be Eemian; secondly that a more or less complete interglacial sequence is represented. The parallel pollen-analytical results from the boreholes at Nørre Lyngby and Skagen have now been published (Glaister \& Gibbard, 1998), again proposing an Eemian age. A close look suggests, however, that either the interglacial at these sites is not the Eemian and/or that large hiatuses occur in these successions. Even allowing for the problems of marine pollen taphonomy, it is hard to see that the temperate substages of an interglacial are represented, and if so, it could not be an Eemian pollen diagram since quite high pollen values of Picea occur almost throughout the proposed interglacial span, whereas Picea is absent from the first half of the Eemian interglacial not only at Hollerup (Andersen, 1965, 1966; Björck et al., 2000) and at North German sites, but also from the well developed Eemian site at Fjøsanger in Norway (Mangerud et al., 1981) and other Scandinavian sites ascribed to the same age. These sites have to be reassessed, in the light of the new correlations be- tween the marine isotope stages and continental sequences.

\section{Conclusion}

For many years, the Eemian or - in Britain - Ipswichian interglacial was considered as one of the best known and least problematic intervals of the Quaternary and perhaps as a model not only of a 'typical' interglacial but also of how the Holocene might have developed in North-West Europe but for the intervention of human disturbance. Many of these certainties, and particularly the differences between the Eemian and the basic pattern of the Holocene are now, however, coming under scrutiny.

The first point to make is that it is now clear that two further interglacial stages intervened between the Eemian and the Holsteinian. At many sites in the North European plain, identification of Eemian deposits is not in doubt because of their relationship to Saalian glacial strata, but elsewhere the traditional palynological criteria, based on sequences of acme zones and particularly a major representation of Carpinus, are apparently breaking down. In Southern England, stratigraphical and palaeontological evidence suggests that the interglacial stage correlated with MIS 7 also possessed these characteristics and the same interval in the Massif Central sequence the Le Bouchet Interglacial (Reille et al., 1998) - also shows a very strong Carpinus zone. Some sites, for example Pianico in northern Italy (Moscariello et al., in press) or Wing in central England (Hall, 1980), where identification to the last interglacial has to be based largely on palynological evidence, cannot be regarded as well dated.

It has been considered for a long time that the Eemian had a shorter duration than the Holsteinian, and, indeed, comparatively than the Holocene, too. This has recently been queried, but there is no doubt that the characteristic interglacial vegetational succession from open environments through pioneer woodland to temperate mixed-oak forest and then the spread of Carpinus took a clearly much shorter time during that interglacial than either during the Holsteinian or Holocene. Differences in rate and nature of vegetational successions may be related to particular features of the Saalian/Eemian glacial/interglacial cycle: (1) the apparent absence of a late-glacial oscillation, at least on the scale of the Younger Dryas; (2) the presence of a marine link not only between the English Channel and the North Sea, but also more directly through to the Baltic and then to the White Sea and the Arctic, a feature related to the timing of isostatic recovery and strongly influencing climatic 
development across the whole area of northern Europe; (3) the survival through the Saalian of refugia for Carpinus, allowing this tree to migrate much more rapidly into Northern Europe than during the Holsteinian or Holocene.

The question of climatic events within the Eemian is far from settled. Not only is the ice-core evidence ambiguous and awaiting further clarification, but the scale and synchroneity of proposed events at various continental sites in both Northern and Southern Europe at present show no clear pattern. In some cases the matter is bedevilled by possible miscorrelation of interglacials, in others by inappropriate methods of investigation, but there is no doubt that climatic fluctuations at some scale, if only on that of Holocene climate, were taking place during the Eemian. What was of local significance, what global, is certainly still a matter for more precise investigation, definition and debate.

The final conclusion has to be that there are still major and interlinked questions to be answered not just about the Eemian, but also about the two preceding, poorly recognised and poorly defined late Middle Pleistocene interglacial stages. Far from being 'cut and dried' this part of the Quaternary offers real challenges for future research.

\section{References}

Aalbersberg, G. \& Litt, T., 1998. Multiproxy climatic reconstructions for the Eemian and Early Weichselian. Journal of Quaternary Science 13: 367-390.

Andersen, S.T., 1965. Interglacialer og interstadialer i Danmarks kvartaer. Meddelser fra Dansk Geologisk Forening 15: 486-506.

Andersen, S.T., 1966. Interglacial vegetational succession and lake development in Denmark. The Paleobotanist 15: 117-127.

Andersen, S.T., 1975. The Eemian freshwater deposit at Egernsund, South Jylland, and the Eemian landscape development in Denmark. Danmarks geologische Undersøgelse A 1974: 49-70.

Antoine, P., 1994. The Somme valley terrace system (northern France): a model of river response to Quaternary climatic variations since 800,000 BP. Terra Nova 6: 453-464.

Atkinson, T.C., Briffa, K.R. \& Coope, G.R., 1987. Seasonal temperatures in Britain during the past 22,000 years reconstructed using beetle remains. Nature 352: 587-592.

Bartlein, P.J., Prentice, I.C. \& Webb T., 1986. Climatic response surfaces from pollen data for some eastern North American taxa. Journal of Biogeography 13: 35-57.

Behre, K. 1974. Die Vegetation im Spätpleistozän von Osterwanna/Niedersachsen. Geologisches Jahrbuch A 18: 3-36.

Behre, K.E. \& Lade, U., 1986. Eine Folge von Eem und 4 Weichsel-Interstadialen in Oerel/Niedersachsen und ihr Vegetationsablauf. Eiszeitalter und Gegenwart 36: 11-36.

Björck, S., Noe-Nygaard, N., Wolin, J., Houmark-Nielsen, M., Jørgen Hansen, H. \& Snowball, I., 2000. Lake development, hydrology and climate: a multi-stratigraphic study of the Hollerup site in Denmark. Quaternary Science Reviews 19: 509-536.

Bridgland, D.R., 1994. Quaternary of the Thames. Geological Conservation Review Series 7. Chapman \& Hall: 441 pp.
Cleveringa, P., Meijer, T., Van Leeuwen, R.J.W., De Wolf, F., Pouwer, R. Lissenberg, T. \& Burger, A.W., 2000. The Eemian type locality at Amersfoort in the central Netherlands: redeployment of old and new data. In: Van Kolfschoten, Th. \& Gibbard, P.L. (eds.): The Eemian - local sequences, global perspectives. Geologie en Mijnbouw / Netherlands Journal of Geosciences 79: 197-216 (this issue).

Coope, G.R., 1974. Interglacial Coleoptera from Bobbitshole, Ipswich, Suffolk. Journal of the Geological Society of London 130 333-340.

Coope, G.R., 1990: The invasion of Northern Europe during the Pleistocene by Mediterranean species of Coleoptera. In: Di Castri, F., Hansen, A.H. \& Debussche, M. (eds.): Biological Invasions in Europe and the Mediterranean Basin. Kluwer (Dordrecht): 203-215.

Coxon, P., 1993. Irish Pleistocene biostratigraphy. Irish Journal of Earth Sciences 12: 83-105.

Dansgaard, W., Johnsen, S.J., Clausen, H.B., Dahl-Jensen, D., Gundestrup, N.S., Hammer, C.U., Hvidberg, C.S., Steffensen, J.P., Sveinbjörnsdottir, A.E., Jouzel, J. \& Bond, G., 1993. Evidence for general instability of past climate from a $250-\mathrm{kyr}$ icecore record. Nature 364: 218-220.

De Beaulieu, J.-L. \& Reille, M., 1984. A long Upper Pleistocene pollen record from Les Echets near Lyons, France. Boreas 13: 111-131.

De Beaulieu, J.-L. \& Reille, M., 1989. The transition from temperate phases to stadials in the long Upper Pleistocene sequence from Les Echets (France). Palaeogeography, Palaeoclimatology, Palaeoecology 72: 147-159.

De Beaulieu, J.-L.\& Reille, M., 1992a. The last climatic cycle at La Grande Pile (Vosges). A new pollen profile. Quaternary Science Reviews 11: 431-438.

De Beaulieu, J.-L. \& Reille, M., 1992b. Long Pleistocene pollen sequences from the Velay Plateau (Massif Central, France). I Ribains maar. Vegetation History and Archaeobotany 1: 233-242.

De Beaulieu, J.-L. \& Reille, M., 1995. Pollen records from the Velay craters: a review and correlation of the Holsteinian Interglacial with isotopic stage 11. Mededelingen Rijks Geologische Dienst 52: $59-70$

Ehlers, J., 1983. The glacial history of north-west Germany. In: Ehlers, J. (ed.): Glacial deposits in North-west Germany. Balkema (Rotterdam): 229-238

Ehlers, J, Kozarski, S. \& Gibbard, P.L. (eds.), 1995. Glacial deposits in North-East Europe. Balkema (Rotterdam): $626 \mathrm{pp}$.

Ehlers, J. \& Stephan, H.-J., 1983. North German till types. In: Ehlers, J. (ed.): Glacial deposits in North-west Germany. Balkema (Rotterdam): 239-247.

Erd, K., 1970. Pollenanalytical classification of the Middle Pleistocene in the German Democratic Republic. Palaeogeography, Palaeoclimatology, Palaeoecology 8: 129-145.

Felix-Henningsen, P., 1983. Palaeosols and their stratigraphical interpretation. In: Ehlers, J. (ed.): Glacial deposits in North-west Germany. Balkema (Rotterdam): 289-295.

Field, M.H., Huntley, B. \& Müller, H., 1994. Eemian climate fluctuations observed in a European pollen record. Nature 371: 779783.

Firbas, F., 1949. Waldgeschichte Mitteleuropas, I. Fischer (Jena): $480 \mathrm{pp}$.

Follieri, M., Magri, D. \& Sadori, L., 1988. 250,000 year pollen record from Valle di Castiglione (Roma). Pollen et Spores 30: 329-356.

Frogley, M.R., Tzedakis, P.C. \& Heaton, T.H.E., 1999. Climatic variability in northwest Greece during the last interglacial. Science 285: 1886-1888.

Gibbard, P.L. 1995. The Pleistocene history of the Lower Thames 
valley. Cambridge University Press (Cambridge): 229 pp.

Glaister, C.G. \& Gibbard, P.L., 1998. Pollen stratigraphy of Late Pleistocene marine sediments at Nørre Lyngby and Skagen, North Denmark. Quaternary Science Reviews 17: 839-854.

Grichuk, V.P., 1969. An experiment in reconstructing some characteristics in climate in the Northern hemisphere during the Atlanticum period of Holocene (in Russian). In: Neustadt, M.J. (ed.): Holocene. Akademia Nauk (Moscow): 41-57.

Grichuk, V.P., 1984. Late Pleistocene vegetational history. In: Velichko, A.A. (ed.): Late Quaternary environments of the Soviet Union. University of Minnesota Press (Minneapolis): 155-178.

GRIP Members, 1993. Climate instability during the last interglacial period recorded in the GRIP ice core. Nature 364: 203207.

Grootes, P.M., Stuiver, M., White, J.W.C., Johnsen, S. \& Jouzel, J., 1993. Comparison of oxygen isotope records from the GISP2 and GRIP Greenland ice cores. Nature 366: 552-554.

Hahne, J., Kemle, S., Merkt, J. \& Meyer, K.-D., 1994. Eem-, weichsel- und saalezeitliche Ablagerungen der Bohrung 'Quakenbrück GE 2'. Geologisches Jahrbuch A 134: 9-69.

Hall, A.R., 1980. Late Pleistocene deposits at Wing, Rutland. Philosophical Transactions of the Royal Society of London B 289: 135-164.

Hollin, J.T., 1977. Thames interglacial sites, Ipswichian sea levels and Antarctic ice surges. Boreas 6: 33-52.

Huntley, B., 1993. The use of climate response surfaces to reconstruct palaeoclimate from Quaternary pollen and plant macrofossil data. Philosophical Transactions of the Royal Society of London B 341: 215-224.

Huntley B. \& Birks, H.J.B., 1983. An atlas of past and present pollen maps for Europe: 0-13,000 years ago. Cambridge University Press (Cambridge): $667 \mathrm{pp}$.

Iversen, J., 1944. Viscum, Hedera and Ilex as climate indicators. Geologiska Föreningens Förhandlingar 66: 463-483.

Iversen, J., 1958. The bearing of glacial and interglacial epochs on the formation and extinction of plant taxa. Uppsala Universitetet Årsskrift 6: 210-215.

Jessen, K. \& Milthers, V., 1928. Stratigraphical and palaeontological studies of interglacial freshwater deposits in Jutland and Northwest Germany. Danmarks geologische Undersøgelse II 48: 1-380.

Knudsen, K.L., 1994. The marine Quaternary in Denmark: a review of new evidence from glacial-interglacial studies. Bulletin of the Geological Society of Denmark 41:203-218.

Kukla, G., McManus, J.F., Rousseau, D.-D. \& Chuine, I., 1997. How long and how stable was the Last Interglacial? Quaternary Science Reviews 16: 605-612.

Litt, T., 1990. Pollenanalytische Untersuchungen zur Vegetationsund Klimaentwicklung während des Jungpleistozäns in den Becken von Gröbern und Grabschütz. Altenburger naturwissenschaftliche Forschungen 5: 92-105.

Litt, T., Junge, F.W. \& Böttger, T., 1996. Climate during the Eemian in north-central Europe - a critical review of palaeobotanical and stable isotope data from central Germany. Vegetation History and Archaeobotany 5: 247-256.

Litt, T. \& Turner, C., 1993. Arbeitsergebnisse der Subkommission für Europäische Quartärstratigraphie: Die Saalesequenz in der Typusregion (Berichte der SEQS 10). Eiszeitalter und Gegenwart 37: 145-148.

Maddy, D., Keen, D.H., Bridgland, D.R. \& Green, C.P., 1991. A revised model for the Pleistocene development of the River Avon, Warwickshire. Journal of the Geological Society of London 148: 473-484.

Mamakowa, K., 1989. Late Middle Polish glaciation, Eemian and Early Vistulian vegetation at Imbramowice near Wrockaw and the pollen stratigraphy of this part of the Pleistocene in Poland. Acta Palaeobotanica 29: 11-176.

Mangerud, J., Sønstegaard, E, Sejrup, H.-P. \& Haldorsen, S., 1981. A continuous Eemian-Early Weichselian sequence containing pollen and marine fossils at Fjøsanger, western Norway. Boreas 10: 138-205.

Martinson, D.G., Pisias, N.G., Hays, J.D., Imbrie, J., Moore, T.C. \& Shackleton, N.J. 1987. Age dating and the orbital theory of the ice ages: development of a high-resolution 0 to 300,000-year chronostratigraphy. Quaternary Research 27: 1-29.

Meijer, T., 1998. References of relevant publications about Eemian deposits: a base for a European Eemian bibliography. SEQS Symposium (Kerkrade, the Netherlands, 1998): $126 \mathrm{pp.}$

Meijer, T., \& Preece, R.C., 2000. A review of the occurrence of Corbicula in the Pleistocene of North-west Europe. Geologie en Mijnbouw / Netherlands Journal of Geosciences 79: 241-255 (this issue).

Menke, B., 1992. Eeminterglaziale und nacheiszeitliche Wälder in Schleswig-Holstein. Berichte des Geologischen Landesamtes Schleswig-Holstein 1: 28-101.

Menke, B. \& Tynni, R., 1984. Das Eeminterglazial und das Weichselfrühglazial von Rederstall/Dittmarschen und ihre Bedeutung für die mitteleuropäische Jungpleistozängliederung. Geologisches Jahrbuch A 76: 3-120.

Moscariello, A., Ravazzi, C., Brauer, A., Chiesa, S., De Beaulieu, J.L., Mangili, C., Reille, M. \& Rossi, S. (in press). A long lacustrine record from the Pianico-Sellere basin (Middle-Late Pleistocene, Northern Italy. Quaternary International.

Müller, H., 1974a. Pollenanalytische Untersuchungen und Jahresschichtenzählungen an der eemzeitlichen Kieselgur von Bispingen/Luhe. Geologisches Jahrbuch A 21, 149-169.

Müller, H., 1974b. Pollenanalytische Untersuchungen und Jahresschichtenzählungen an der holsteinzeitlichen Kieselgur von Münster-Breloh. Geologisches Jahrbuch A 21, 107-140.

NLfB (Niedersächsisches Landesamt für Bodenforschung), 1993. Quartärgeologische Übersichtskarte von Niedersachsen und Bremen, $1: 500$ 000. NLfB (Hannover).

Phillips, L., 1974. Vegetational history of the Ipswichian/Eemian interglacial in Britain and continental Europe. New Phytologist 73: 589-604.

Picard, K., 1960. Zur Untergliderung der 'Saalevereisung' im Westen Schleswig-Holsteins. Zeitschrift der. deutschen geologischen Gesellschaft 112: 316-352.

Pons, A., J. Guiot, De Beaulieu, J.-L. \& Reille, M., 1992. Recent contributions to the climatology of the last glacial-interglacial cycle based on french pollen sequences. Quaternary Science Reviews 11:439-448.

Preece, R.C., 1995. Mollusca from interglacial sediments at three critical sites in the Lower Thames. In: Bridgland, D.R., Allen, P. \& Haggart, B.A. (eds.): The Quaternary of the lower reaches of the Thames. Quaternary Research Association Field Guide (Durham): 53-60.

Preece, R.C., 1999. Mollusca from last interglacial fluvial deposits of the river Thames at Trafalgar Square, London. Journal of Quaternary Science 14: 77-89.

Reille, M. \& De Beaulieu, J.-L., 1990. Pollen analysis of a long upper Pleistocene continental sequence in a Velay maar. Palaeogeography, Palaeoclimatology, Palaeoecology 80: 35-48.

Reille, M. \& De Beaulieu, J.-L., 1995. Long Pleistocene pollen records from the Praclaux Crater, South-Central France. Quaternary Research 44: 205-215.

Reille, M., De Beaulieu, J.-L, Andrieu, V., Guenet, P. \& Goeury, C., 1998. A long pollen record from Lac du Bouchet Massif, central France: for the period ca. 325 to $100 \mathrm{ka} \mathrm{BP}$ (OIS 9c to OIS 5e). Quaternary Science Reviews 17: 1107-1124. 
Sánchez Gõni, M.F., Eynaud, F., Turon, J.L. \& Shackleton, N.J., 1999. High resolution palynological record off the Iberian margin: direct land-sea correlation for the last interglacial complex. Earth and Planetary Science Letters 171: 123-137.

Schreve, D. C. 1997. Mammalian biostratigraphy of the later Middle Pleistocene in Britain. Unpublished Ph.D. thesis University of London.

Seidenkrantz, M.-S., Kristensen, P. \& Knudsen, K.L., 1995. Marine evidence for climatic stability during the last interglacial in shelf records from northwest Europe. Journal of Quaternary Science 10: 77-82.

Selle, W., 1962. Geologische und vegetationskundliche Untersuchungen an einigen wichtigen Vorkommen des letzten Interglazials in Nordwestdeutschland. Geologisches Jahrbuch 79: 295-352.

Shackleton, N.J., 1969. The last interglacial in the marine and terrestrial records. Proceedings of the Royal Society of London B 174: 135-154.

Simpson, I.M. \& West, R.G., 1958. On the stratigraphy and palaeobotany of a late-Pleistocene organic deposit at Chelford, Cheshire. New Phytologist 57: 239-50.

Stephan, H.-J. \& Menke, B., 1994. Das Pleistozän in SchleswigHolstein. Berichte des Geologischen Landesamtes SchleswigHolstein 3: 19-62.

Stremme, H.E., 1964. Die Warmzeiten vor und nach der WartheEiszeit in ihren Bodenbildungen bei Böxlund (westl. Flensburg). Neues Jahrbuch für Geologie und Paläontologie, Monatshefte: 237-247.

Stremme, H.E. \& Menke. B., 1980. Quartär-Excursion in Schleswig-Holstein. Geologisches Landesamt (Kiel): 132 pp.

Taylor, K.C., Hammer, C.U., Alley, R.B., Clausen, H.B., DahlJensen, D., Gow, A.J., Gundestrup, N.S., Kipf-Stuhl, J., Moore, J.C. \& Waddington, E.D., 1993. Electrical conductivity measurements from the GISP2 and GRIP Greenland ice cores. Nature 366: 549-552.

Turner, C., 1970. The Middle Pleistocene deposits at Marks Tey, Essex. Philosophical Transactions of the Royal Society of London B 257: 373-440.

Turner, C., 1998. Volcanic maars, long Quaternary sequences and the work of the INQUA Subcommission on European Quaternary Stratigraphy. Quaternary International 47/48: 41-49.

Turner, C. \& West, R.G., 1968. The subdivision and zonation of interglacial periods. Eiszeitalter und Gegenwart 19: 93-101.

Tzedakis, P.C. , 1994. Vegetation change through glacial-interglacial cycles: a long pollen sequence perspective. Philosophical Transactions of the Royal Society of London B 345: 403-432.

Urban, B., 1995. Palynological evidence of younger Middle Pleistocene interglacials (Holsteinian, Reinsdorf and Schöningen) in the Schöningen open cast lignite mine (eastern Lower Saxony, Germany). Mededelingen Rijks Geologische Dienst 52: 175186.
Van Kolfschoten, Th., Roebroeks, W. \& Vandenberghe, J. 1993. The Middle and Late Pleistocene sequence at Maastricht-Belvédère: the type locality of the Belvédère Interglacial. Mededelingen Rijks Geologische Dienst Nieuwe Serie 47: 81-91.

Van Leeuwen, R.J.W., Beets, D., Bosch, J.H.A., Burger, A.W., Cleveringa, P., Van Harten, D., Herngreen, G.F.W., Kruk, R.W., Langereis, C.G., Meijer, T., Pouwer, R., \& De Wolf, H., 2000. Stratigraphy and integrated facies analysis of the Eemian in Amsterdam-Terminal. In: Van Kolfschoten, Th. \& Gibbard, P.L. (eds.): The Eemian - local sequences, global perspectives. Geologie en Mijnbouw / Netherlands Journal of Geosciences 79: 161-196 (this issue).

Wansa, S. \& Wimmer, R., 1990. Geologie des Jungpleistozäns von Gröbern und Grabschütz. Altenburger naturwissenschaftliche Forschungen 5: 49-91.

West, R.G., 1957. Interglacial deposits at Bobbitshole, Ipswich. Philosophical Transactions of the Royal Society of London B 241: 1-31.

West, R.G., 1969. Pollen analyses from interglacial deposits at Aveley and Grays, Essex. Proceedings of the Geologists' Association 80: $271-282$.

West, R.G., 1980. Pleistocene forest history in East Anglia. New Phytologist 85: 571-622.

West, R.G., Lambert, C.A. \& Sparks, B.W., 1964. Interglacial deposits at Ilford, Essex. Philosophical Transactions of the Royal Society of London B 247: 185-212.

Woillard, G.M., 1975. Recherches palynologiques sur le Pléistocène dans l'est de la Belgique et dans les Vosges Lorraines. Acta Geographica Lovaniensia 14: 1-118.

Woillard, G.M., 1978. Grande Pile peat bog: A continuous pollen record from the last 140.000 years. Quaternary Research 9: 121.

Zagwijn, W.H., 1961. Vegetation, climate and radiocarbon datings in the Late Pleistocene of the Netherlands. Part 1: Eemian and Early Weichselian. Mededelingen Geologische Stichting Nieuwe Serie 14: 15-45.

Zagwijn, W.H., 1995. Eem Valley near Amersfoort - type-site of the Eemian. In: Schirmer, W. (ed.): Quaternary field trips in Central Europe, 2, Field trips on special topics, INQUA, XIV International Congress (Berlin, 1995). F. Pfeil (München): 651-653.

Zagwijn, W.H., 1996. An analysis of Eemian climate in western and central Europe. Quaternary Science Reviews 15: 451-469.

Ziemus, H. 1980. Palynologische Untersuchungen am limnischen Jungpleistozän von Haalmoor bei Burg/Dithmarschen (Schleswig-Holstein). Schriften Naturwissenschaftlicher Verein für Schleswig-Holstein 50: 71-80.

Ziemus, H. 1981. Palynologische Untersuchungen am terrestrischen Jungpleistozän von Schalkholz, Kreis Dithmarschen (Schleswig-Holstein). Schriften Naturwissenschaftlicher Verein für Schleswig-Holstein 51:25-36. 